\section{Response to: 'Calprotectin is not independent from baseline erosion in predicting radiological progression in early rheumatoid arthritis' by Chevreau et al}

We appreciate the additional data regarding calprotectin and radiographic progression provided by Chevreau et $a l^{1}$ as an eLetter addressing our published research paper. ${ }^{2}$ It is important to explore new biomarkers in different cohorts of patients with early and established rheumatoid arthritis (RA). Calprotectin levels have previously been shown to be associated with joint damage in established RA. ${ }^{34}$ Hammer et $a l^{5}$ have shown that calprotectin was an independent predictor of radiographic joint damage after 10 years of follow-up. Chevreau et al present data on baseline calprotectin as a predictor of rapid radiographic progression (defined as an increase of $\geq 5$ van der Heijde Sharp score units/year) in a large cohort of patients with early RA, and did not find calprotectin to be associated with structural damage when baseline erosions were considered. ${ }^{1}$

In order to address the issues raised by Chevreau et al ${ }^{1}$ we performed additional statistical analyses. When introducing baseline van der Heijde modified Sharp erosion score in the multivariate model (including erythrocyte sedimentation rate, $\mathrm{C}$ reactive protein, age, gender, Clinical Disease Activity Index and rheumatoid factor (RF)), baseline erosion score was a significant predictor of radiographic progression (OR 1.14, 95\% CI 1.02 to 1.28; table 1). Importantly, calprotectin in the highest quartile remained a significant independent predictor of radiographic damage in the multivariate model (OR 3.52, 95\% CI 1.15 to 10.72; table 1). RF was a stronger predictor than anticitrullinated peptide antibody (ACPA) in univariate models; thus, we chose to include RF in our initial model. ${ }^{2}$ When assessing the multivariate model including ACPA instead of RF, both calprotectin and baseline erosions remained significant independent predictors of radiographic progression, while ACPA was not a significant predictor (OR 1.27, 95\% CI 0.52 to $3.08, \mathrm{p}=0.60$ ).

Comparison between cohorts should be done with caution, and the Aiming for Remission in Rheumatoid Arthritis: a Randomized Trial Examining the Benefit of Ultrasonography in a Clinical TIght Control Regimen (ARCTIC) ${ }^{6}$ and Etude et Suivi des Polyarthrites Indifférenciées Récentes (ESPOIR) cohorts ${ }^{7}$ are different. Serologically, 44\% vs 39\% of patients were positive for RF-IgM and ACPA in the ESPOIR cohort compared with $71 \%$ and $82 \%$ in the ARCTIC cohort. Treatment strategies were different in the two cohorts; in ESPOIR there were no protocol-based treatment strategies, as opposed to ARCTIC with a structured, aggressive tight control algorithm aiming for remission. In the ARCTIC cohort, 41\% of disease-modifying antirheumatic drugnaïve patients with early RA progressed radiographically during the 2 years of follow-up, with radiographic progression defined as $\geq 1$ unit/year from 0 to 24 months. ${ }^{2}$ However, rapid radiographic progression was rare, occurring in only 11 out of the 230 patients included in the full analyses set.

In modern RA care, patients are identified at an early stage and often before radiographic damage is evident. In such a setting, our results indicate that calprotectin may be an independent predictor of radiographic damage, but the role of calprotectin needs to be further investigated in different cohorts before being fully implemented in routine care.

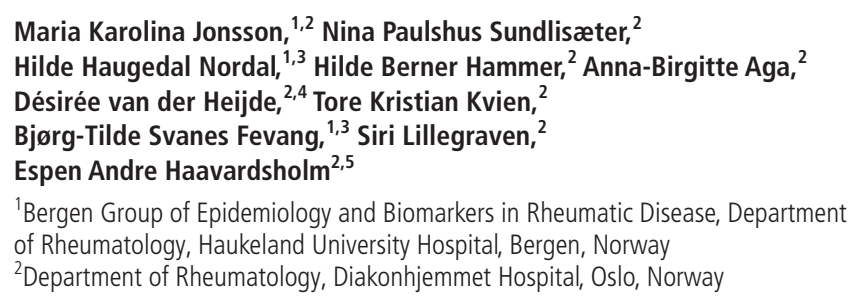

Maria Karolina Jonsson, ${ }^{1,2}$ Nina Paulshus Sundlisæter, ${ }^{2}$ Hilde Haugedal Nordal, ${ }^{1,3}$ Hilde Berner Hammer, ${ }^{2}$ Anna-Birgitte Aga ${ }_{\star}{ }^{2}$ Désirée van der Heijde, ${ }^{2,4}$ Tore Kristian Kvien, Bjørg-Tilde Svanes Fevang, ${ }^{1,3}$ Siri Lillegraven, Espen Andre Haavardsholm

of Rheumatology, Haukeland University Hospital, Bergen, Norway

${ }^{2}$ Department of Rheumatology, Diakonhjemmet Hospital, Oslo, Norway

Table 1 Predictors of radiographic progression $\geq 1$ unit/year from 0 to 24 months $(n=215)$

\begin{tabular}{|c|c|c|c|c|}
\hline \multirow[b]{2}{*}{ Baseline variables } & \multicolumn{2}{|l|}{ Univariate } & \multicolumn{2}{|l|}{ Multivariate } \\
\hline & OR & $p$ value & OR & $\mathrm{p}$ value \\
\hline Age & 1.04 (1.02 to 1.07$)$ & $<0.001$ & 1.02 (1.00 to 1.05$)$ & 0.09 \\
\hline Gender (female) & 0.61 (0.35 to 1.07 ) & 0.09 & 0.71 (0.36 to 1.37 ) & 0.30 \\
\hline \multicolumn{5}{|l|}{ Calprotectin quartile (range) } \\
\hline First quartile $(186-556 \mu \mathrm{g} / \mathrm{L})$ & Ref & Ref & Ref & Ref \\
\hline Second quartile (567-1028 $\mu \mathrm{g} / \mathrm{L})$ & 1.51 (0.66 to 3.46 ) & 0.33 & 1.55 (0.60 to 4.01$)$ & 0.37 \\
\hline Third quartile (1045-2158 $\mu \mathrm{g} / \mathrm{L})$ & 1.39 (0.61 to 3.20$)$ & 0.44 & 0.97 (0.36 to 2.60$)$ & 0.94 \\
\hline Fourth quartile $(2235-48079 \mu \mathrm{g} / \mathrm{L})$ & $6.06(2.62$ to 14.02$)$ & $<0.001$ & $3.62(1.20$ to 10.93$)$ & 0.02 \\
\hline \multicolumn{5}{|l|}{ ESR, quartile (range) } \\
\hline First quartile (1-10 mm/hour) & Ref & Ref & Ref & Ref \\
\hline Second quartile (11-18 mm/hour) & 1.07 (0.47 to 2.43 ) & 0.87 & 0.80 (0.31 to 2.04$)$ & 0.64 \\
\hline Third quartile (19-31 mm/hour) & $1.26(0.55$ to 2.86$)$ & 0.59 & $0.82(0.30$ to 2.19$)$ & 0.69 \\
\hline Fourth quartile (32-110 mm/hour) & 3.74 (1.64 to 8.52$)$ & 0.002 & 0.99 (0.29 to 3.35$)$ & 0.99 \\
\hline \multicolumn{5}{|l|}{ CRP, quartile (range) } \\
\hline First quartile $(0.3-2.8 \mathrm{mg} / \mathrm{L})$ & Ref & Ref & Ref & Ref \\
\hline Second quartile (3-6 mg/L) & 0.69 (0.29 to 1.64$)$ & 0.41 & 0.41 (0.15 to 1.09$)$ & 0.07 \\
\hline Third quartile (7-16 mg/L) & 1.29 (0.54 to 3.04$)$ & 0.57 & 0.75 (0.25 to 2.19$)$ & 0.59 \\
\hline Fourth quartile (18-117 mg/L) & 2.85 (1.20 to 6.76$)$ & 0.02 & 0.89 (0.24 to 3.22$)$ & 0.85 \\
\hline CDAI $(0-76)$ & $1.02(1.00$ to 1.04$)$ & 0.08 & 1.01 (0.98 to 1.04 ) & 0.50 \\
\hline RF positivity & 1.86 (0.99 to 3.48$)$ & 0.053 & $1.92(0.91$ to 4.06$)$ & 0.09 \\
\hline vdHS erosion score (0-280) & 1.18 (1.07 to 1.29$)$ & 0.001 & 1.14 (1.01 to 1.27$)$ & 0.03 \\
\hline
\end{tabular}

$P$ values $<0.05$ in bold.

CDAl, Clinical Disease Activity Index; CRP, C reactive protein; ESR, erythrocyte sedimentation rate; $h$, hour; L, liter; mg, milligram; mm, millimeter; OR, odds ratio; Ref, reference category (lowest quartile as reference); RF, rheumatoid factor; $\mu \mathrm{g}$, microgram; vdHS, van der Heijde modified Sharp. 
${ }^{3}$ Broegelmann Research Laboratory, Department of Clinical Science, University of Bergen, Bergen, Norway

${ }^{4}$ Department of Rheumatology, Leiden University Medical Center, Leiden, The Netherlands

${ }^{5}$ Institute of Health and Society, University of Oslo, Oslo, Norway

Correspondence to Dr Maria Karolina Jonsson, Bergen Group of Epidemiology and Biomarkers in Rheumatic Disease, Department of Rheumatology, Haukeland University Hospital, Bergen 5021, Norway; jonssonmk@gmail.com

Handling editor Josef S Smolen

Acknowledgements We would like to thank Inge Dale at CalproLab, Marianne Eidsheim at Broegelmann Research Laboratory, Ellen Moholt and Camilla Fongen at Diakonhjemmet Hospital, and the ARCTIC study group.

Competing interests MKJ reports grants from Norwegian Extra Foundation for Health and Rehabilitation and non-financial support from Calpro AS during the conduct of the study. TKK has received fees for speaking and/or consulting from AbbVie, Biogen, BMS, Boehringer Ingelheim, Celgene, Celltrion, Eli Lilly, Epirus, Hospira, Merck Serono, MSD, Mundipharma, Novartis, Oktal, Orion Pharma, Hospira/ Pfizer, Roche, Sandoz and UCB, and received research funding to Diakonhjemmet Hospital from AbbVie, BMS, MSD, Pfizer, Roche and UCB. EAH has received research funding from Pfizer, UCB, Roche, MSD and AbbVie, honorariums as a speaker from Pfizer, UCB, Roche and AbbVie, and honorariums for development of educational material from Pfizer, and has sat on advisory boards for Pfizer.

Provenance and peer review Commissioned; internally peer reviewed.

(c) Article author(s) (or their employer(s) unless otherwise stated in the text of the article) 2018. All rights reserved. No commercial use is permitted unless otherwise expressly granted.

\section{Check for updates}

To cite Jonsson MK, Sundlisæter NP, Nordal HH, et al. Ann Rheum Dis 2018;77:e85.
Received 22 December 2017

Accepted 23 December 2017

Published Online First 10 January 2018

\section{SLinked}

http://dx.doi.org/10.1136/annrheumdis-2017-212816

Ann Rheum Dis 2018:77:e85. doi:10.1136/annrheumdis-2017-212869

\section{REFERENCES}

1 Chevreau M, Paclet MH, Romand X, et al. Calprotectin is not independent from baseline erosion in predicting radiological progression in early Rheumatoid Arthritis. Ann Rheum Dis 2018;77:e84.

2 Jonsson MK, Sundlisæter NP, Nordal HH, et al. Calprotectin as a marker of inflammation in patients with early rheumatoid arthritis. Ann Rheum Dis 2017;76:2031-7.

3 Hammer HB, Odegard S, Fagerhol MK, et al. Calprotectin (a major leucocyte protein) is strongly and independently correlated with joint inflammation and damage in rheumatoid arthritis. Ann Rheum Dis 2007:66:1093-7.

4 Nordal HH, Brun JG, Hordvik M, et al. Calprotectin (S100A8/A9) and S100A12 are associated with measures of disease activity in a longitudinal study of patients with rheumatoid arthritis treated with infliximab. Scand J Rheumatol 2016;45:274-81.

5 Hammer HB, Ødegård S, Syversen SW, et al. Calprotectin (a major S100 leucocyte protein) predicts 10-year radiographic progression in patients with rheumatoid arthritis Ann Rheum Dis 2010;69:150-4.

6 Haavardsholm EA, Aga AB, Olsen IC, et al. Ultrasound in management of rheumatoid arthritis: ARCTIC randomised controlled strategy trial. BMJ 2016;354:i4205.

7 Combe B, Benessiano J, Berenbaum F, et al. The ESPOIR cohort: a ten-year follow-up of early arthritis in France: methodology and baseline characteristics of the 813 included patients. Joint Bone Spine 2007;74:440-5. 